\title{
Discursive Interactions Between Museum Educators and Students: A Case Study in a Science Museum Based on the Contributions of Bakhtin and the Circle
}

Guilherme da Silva Lima, Jessica Norberto Rocha

Keywords Resumo This paper investigated the interactions between the Science museums; museum educator and a class from a public school during a visit to a

Discourse science museum in the state of São Paulo. The concept of dialogism, interactions; proposed by Bakhtin and the Circle, is used as a theoretical reference Dialogism; Museum for analysis. The methodology adopted was the case study. The data educator; Non- were collected in audio and video; the excerpts were selected and formal education. transcribed for analysis. In both parts analyzed, the dialogue was centered on and conducted by the museum educators and their knowledge, instead of the students, and there were difficulties in establishing a communication that considered different interpretations of the objects. The results indicate the recurrence of two types of interaction: discourses with the shift of speakers controlled by the museum educator and discourses that silence students, both classified as monologic. In this sense, there are still challenges to be explored in future studies and practices of initial and continued professional qualification of these educators.

Submitted on 05th June 2020 Accepted on 03rd September 2020 Published on 09th February 2021

\section{Introduction}

Science museum contributions to science education have been highlighted by several researchers (Marandino \& Ianelli, 2012; Marandino et al., 2018; Rodrigues \& Afonso, 2015; Scalfi et al., 2019; Valente et al., 2005), particularly because it prompts the interaction between diverse audiences and elements from the technological and the scientific culture.

Exhibitions in science museums have communicative features that aim to approximate visitors to the objects and the themes on display. Among the recurrent communicative strategies in museums are panels with texts, images, audios, videos, and objects that allow physical interaction and immersion, as well as the dialogue with museum educators and members of the institution (Cazelli \& Coimbra, 2008; Cazelli \& Valente, 2019; Marandino, 2001). 
In the present paper, we adopt the term "museum educators" (Cazelli \& Valente, 2019; Costa, 2019; Costa et al., 2018) to emphasize the relevance of such professionals who mediate the exhibition for the public and perform several tasks in the educational and communicational dimension in these institutions. Similar to other communicative practices offered by museums, the interactions between educators and visitors can contribute to the information on museum objects and the exhibition in general.

The present study case aims to investigate the interactions between museum educators and a class of public-school students in the state of São Paulo, Brazil, during their visit to a science museum. We rely on contributions from the field of science education and education in non-formal spaces regarding museum educators and ground our analysis on the theoretical contributions of Bakhtin and the Circle, especially the concept of dialogism. It is noteworthy that investigating discursive interactions between educators and visitors is essential to understand how one of the most diverse educational activities offered by museums can occur. Therefore, the results of this investigation can indicate forms of reorganizing these activities, of reflecting and proposing initial and continued professional qualification for museum educators.

\section{Science museum educators and school visits}

Educators became more frequent members of staff in science museums after the 1920s, although having someone demonstrate the museum collection has been common practice since the 17th-century cabinets of curiosities (Carlétti \& Massarani, 2015). In the 1960s, at the same time, school visits became very present in museums, important developments in the educational programs in the institutions were verified (Martins, 2006).

In Brazil, it is common for visits to be guided by museum educators (Carlétti \& Massarani, 2015; Cazelli \& Valente, 2019; Costa, 2019; Marandino, 2008) and school students are the most frequent visitors (Barba et al., 2018; Cazelli, 2005; Marandino, 2008). The education performed in science museums displays specific characteristics turned to the interaction between visitors (likely students), museum educators and objects - which are, according to Marandino (2008), pivotal elements and the soul of museums. These interactions comprehend, in addition to the sharing of knowledge between subjects, affective, ludicrous and manipulative factors as well as the influence of perception, emotion and memory (Bizerra, 2009; Oliveira et al., 2014).

Shaby, Assaraf and Tal (2018) argue that educators play a significant role in the educational agenda of institutions. Several authors highlight the importance of these professionals in non-formal education, such as Rodari and Merzagora (2007), for whom they are considered "the only 'museum device' that is really bidirectional and interactive" (p. 10).

Marandino (2008) underscores that museum educators play a fundamental role "as they realize the communication between the institution and the audience and foster dialogue with visitors regarding the issues present in the museum, granting them 
new meanings" (p. 28). Piqueras and Achiam (2019) also argue that educators are keyelements in the learning experience at a museum; and Massarani et al. (2019) highlight the dialogue between visitors and educators can be fruitful because this professional can make these interactions complex by adding scientific terms, developing hypothesis and explanations on a particular phenomenon, as well as by investing in the visitors' previous knowledge to relate it to the themes of the exhibition. Mora (2007) highlights that educators have "a fundamental role when their training comprehends the possibility of addressing a public of diversified interests, ages, goals and cognitive levels" (p. 24)1.

All these possibilities, however, pose challenges for these professionals. Shaby, Assaraf and Tal (2018) indicate a determining factor in the interaction between educators and their public: the former needs to support the latter based on very little information about them and their histories. Therefore, they need to trust their previous experiences and develop, from a series of connections established in the course of their professional education and activity, a specific language for each age as well as a set of specific skills and strategies to shape their knowledge into suitable content for mediation and dialogue.

In some cases, they fail the challenge as it requires good initial and continued professional qualification, practice and training. Usually, educators are protagonists during the visits and approach the subject of the exhibition unilaterally in the so-called deficit model of science communication, in which an expert explains scientific concepts to a non-expert (Brossard \& Lewenstein, 2009). Rodrigues and Afonso (2015), for example, after analyzing 97 dialogues between educators and 14-15-year old students in a science museum, verified that the most common intervention by educators was the explanation of phenomena by transmitting information linearly.

Researchers in the field of science communication and non-formal science education have argued for the relevance of adopting models, in science museums, that allow visitors to activate their own knowledge and previous experiences, and the visits to foster dialogue and knowledge exchange. According to Marandino (2008),

The process of science communication in museums must be done in order to guarantee conceptual accuracy, but, at the same time, promote the approximation of ideas exposed by the audience, leading them to reflect, ask, doubt and search for more and for new information on the theme (p. 23) 2 .

Marandino (2008) also explains there are two common types of guided museums visits: the "lecture-visit" which is the detailed approach to the theme of the exhibition with little interaction; and the "guided discussion," in which the educator asks questions to promote debate for pre-established pedagogical purposes. Finally, Marandino claims that

It is interesting that the indicated visit modalities are integrated to achieve

\footnotetext{
1 "um papel fundamental quando seu treinamento contempla a possibilidade de se dirigir a públicos variados em interesses, idades, metas e níveis cognitivos".

2 "o processo de comunicação da ciência na instituição museal deve ser feito de modo a garantir a correção conceitual, mas, ao mesmo tempo, promover a aproximação das ideias expostas pelo público, levando-o a refletir, a perguntar, a duvidar e a querer buscar mais e novas informações sobre o tema abordado".
} 
different levels of interaction. Actually, the most interesting is to value, during exhibitions and mediations, the type of interaction that promotes dialogue and the audience's participation (Marandino, 2008, p. 23) .

Investigating and exploring the communication and the discursive interactions between educators and their public (students, presently) is a way of understanding how non-formal education in science and science communication are developed in museums. In the next section, we approach the concept of dialogism proposed by Bakhtin and the Circle, the theoretical background used to analyze those interactions.

\section{Dialogism according to Bakhtin and the Circle}

Contributions of Bakhtin and the Circle were used to analyze museum interactions but, in particular, the concept of dialogism. Dialogism is an inherent property of language; therefore, each and every communication is dialogic:

a property of any discourse. It is the natural orientation of any living discourse. On all its routes toward the object, in all its directions, the word encounters an alien word and cannot help encountering it in a living, tension-filled interaction (Bakhtin, 2010a, p. 88) $)^{4}$.

According to Brait (2005), dialogism recognizes the non-interruption of language and understands enunciations as a link in the continuous chains of discursive communication. The author also considers two additional dimensions of dialogism: the first means that "dialogism concerns the permanent dialogue, not always symmetric and harmonious, between the different discourses that form a community, a culture, and a society" (Brait, 2005, p. 94) ; and the second that "dialogism concerns the relations that are established between the self and the other in the discursive processes historically situated by subjects who, in turn, situate themselves and are situated by these discourses" (Brait, 2005, p. 95) ${ }^{6}$.

Based on these assumptions, as well as in readings of the Bakhtin and the Circle, Lima and Giordan (2017) summarize two analytical axes to interpret dialogical relations in communicative processes, that are enunciated as relations: discourse-object and relations discourse-answer.

Discourse-object relations refers to the fact that every object in discourse has already been evaluated. According to Bakhtin, a world of objects without evaluation is

\footnotetext{
3 "É interessante que as modalidades de visita indicadas sejam trabalhadas de forma combinada, conseguindo, assim, múltiplos níveis de interação. Na verdade, o mais interessante é valorizar, nas exposições e na mediação, aquele tipo de interação que promove o diálogo e a fala dos visitantes".

4 Bakhtin, M. M. Discourse in the Novel. In: The Dialogic Imagination. Austin: University of Texas Press. 1981. 259-422.

5 "o dialogismo diz respeito ao permanente diálogo, nem sempre simétrico e harmonioso, existente entre os diferentes discursos que configuram uma comunidade, uma cultura, uma sociedade".

6 "o dialogismo diz respeito às relações que se estabelecem entre o eu e o outro nos processos discursivos instaurados historicamente pelos sujeitos, que por sua vez, se instauram e são instaurados por esses discursos"
} 
only possible for the Biblical Adam. Bakhtin (2010a) argues that:

Any concrete discourse (utterance) finds the object at which it was directed already as it were overlain with qualifications, open to dispute, charged with value, already enveloped in an obscuring mist - or, on the contrary, by the "light" of alien words that have already been spoken about it. It is entangled, shot through with shared thoughts, points of view, alien judgments and accents. (p. 86) ${ }^{7}$.

Due to several tensions of communication, an utterance "cannot fail to brush up against thousands of living dialogic threads, woven by social-ideological consciousness around the given object of an utterance cannot fail to become an active participant in social dialogue" (Bakhtin, 2010a, p. 86) ${ }^{8}$. Therefore, discourse-object relations mention and promote interaction between the several positions toward a certain object of enunciation.

According to Lima and Giordan (2017), discourse-answer relations focus on the speakers. Voloshinov (2017) highlights that utterances are socially generated - if, on the one hand, it is enunciated by someone; on the other hand, it is oriented to someone else. Therefore, utterances hold the seed of an answer, that is, utterances trigger an evaluative orientation in the listener (Voloshinov, 2017). Bakhtin $(2006)^{9}$ claims that:

But the utterance is related not only to preceding but also to subsequent links in the chain of speech communion. When a speaker is creating an utterance, of course, these links do not exist. But from the very beginning, the utterance is constructed while taking into account possible responsive reactions, for whose sake, in essence, it is actually created. (p. 301)

Therefore, Bakhtin highlights the importance of the other for whom the utterance is constructed. The orientation toward this other is an essential characteristic of utterances and determines the type of communication established between subjects. According to Lima e Giordan (2017):

The definition of this assumed interlocutor leads to the delimitation of the symbolic universe and the determining circle, then the utterance must be composed of elements shared by all the subjects in the verbal interaction, otherwise it becomes impossible. (p. 88) $)^{10}$.

Therefore, the dialogue between a given subject and an audience of scientists is completely different from a dialogue between the same subject and primary school students, even if the topic is the same.

7 See Footnote 4.

8 See Footnote 4. p. 276.

9 Bakhtin, M. Speech genre and other late essays. Austin: Texas University Press, 1986. p. 94.

10 Original: “a determinação do interlocutor presumido acarreta a delimitação do universo simbólico e do círculo determinante usado, logo o enunciado deverá ser composto por elementos conhecidos por todos os sujeitos que compõem a interação verbal, caso contrário a comunicação é inviável”. 
It is noteworthy that such analytical axes (discourse-object and discourseanswer) should not be interpreted binarily, since every utterance necessarily establishes relations with both the discourse object and the answer. The axes must be conceived as a theoretical tool that allows the analyses to distinguish and to focus on certain aspects of a communicative act between individuals.

Understanding dialogism and using it as analytical category demands, nonetheless, yet another concept proposed by Bakhtin and the Circle: heteroglossia. Heteroglossia means the multiplicity of voices in an utterance and in the chain of social communication, which implies that a voice does not represent the utterance of a speaker, but their social perspective. Therefore, the existence of several speakers, but only one voice in a given dialogue is possible when all subjects construct similar meanings and agree with one another. On the other hand, there are dialogues in which a single speaker conveys different social voices. Faraco (2009) explains that:

According to Bakhtin, heteroglossia matters less than the dialogism of social voices, that is, it is the sociocultural encounter of these voices and the dynamic therein established: they support, they illuminate one another, they oppose partially or totally, they dilute one into the other, they parody, imitate one another, they polemize implicitly or explicitly and so on (p. 58 $)^{11}$.

Bakhtin, in his analysis of the novel, proposes these categories to understand the plurality of social voices: polyphony and monologism. Bakhtin's work on Dostoevsky uses both concepts as one antagonistic unity that expresses the typical forms of the novel. Despite the origins in the novel, we share Tezza's interpretation: "polyphony is more of a worldview than a technical category. We defend the hypothesis that the concept of polyphony comes rather as an ethical category than a literary category" (Tezza as cited in Faraco, 2009, p. 79) ${ }^{12}$. Because the concepts of polyphony and monologism are created antagonistically, we can conceive both as ethical categories, a condition that allows us to apply them in contexts beyond literature. It is noteworthy that the present work conceives monologism as "a ready-made truth" (Bakhtin, 2010b, p. 125) ${ }^{13}$, and polyphony indicates the presence of equipollent discursive interactions and relations between social voices. These concepts are valuable to understand the production of discursive interaction and the relations between social voices present in a dialogue.

11 "Para Bakhtin, importa menos a heteroglossia como tal e mais a dialogização das vozes sociais, isto é, o encontro sociocultural dessas vozes e a dinâmica que aí se estabelece: elas vão se apoiar mutuamente, se inter iluminar, se contrapor parcial ou totalmente, se diluir em outras, se parodiar, se arremedar, polemizar velada ou explicitamente e assim por diante".

12 Original: "polifonia é mais uma visão de mundo do que uma categoria técnica. Nossa hipótese é que o conceito de polifonia emerge antes como uma categoria ética do que como uma categoria literária”

13 Bakhtin, M. Problems of Dostoevsky's Poetics. Minneapolis: University of Minnesota Press, 1984. p. 110. 


\section{Method}

This research focuses on the discursive interactions established by museum educators during school visits to science museums and it is qualified as a case study to be approached qualitatively based on the theoretical notions of Bakhtin and the Circle, especially the concept of dialogism (Bakhtin, 2010a, 2010b, Voloshinov, 2017). We aim to analyze discursive interactions between museum educators and school students during an interactive exhibition at a science museum in the city of São Paulo. This will allow us to understand the characteristics of the dialogues, especially the ones related to enunciative chains, to the relations between utterances and discursive objects (discourse-object relations) and relations between utterances and speakers (discourseanswer relations).

The discursive interactions analyzed here were recorded on audio and video during the visit of one school group to an interactive exhibition at a science museum in the city of São Paulo. The group was composed of 38 students from the $9^{\text {th }}$ grade, 26 female and 12 male students, ranging from 13 to 16 years old, monitored by two school teachers from a public school in São Paulo. The recording was authorized by all participants: students and their legal guardians, teachers and the museum, after consulting the employees working in the exhibition. The names of subjects and institutions are not mentioned with respect to their privacy and anonymity.

The guided visit was the last stage of a didactic sequence on micro and macrocosm. The visit to the museum aimed to address the subjects of that sequence, especially in the sections dedicated to Astronomy and Chemistry. The schoolteacher also recognized that the visit would contribute to the students' general education, in addition to the subject of the classes. It is noteworthy that the researcher was present in all of the stages of the didactic sequence conducted by the science teacher, of which the visit was the final stage. Therefore, the information presented here is part of a bigger set of data used in the analysis of science communication within formal education [see Lima (2016) for details].

The visit lasted one hour and thirty-five minutes. The museum educators who guided the sections of the visit were designated by the museum according to their daily work schedule. This means that the educators received students as they normally would receive any other school group and were not trained nor received any specific orientation regarding their participation in the research.

The researcher collected the data through non-participant observation. The visit was recorded by both the researcher's video camera as he followed the group and a portable device kept by the teacher (author of the didactic sequence) during the visit. Video and audio recordings were analyzed and the recordings of the Astronomy and Chemistry museum sections, which lasted 34 and 18 minutes, respectively, were selected. The selection of discursive interactions relied on the following criteria: 1) proximity to the topics studied in class during the didactic sequence, which allowed us to exclude part of the recording, as students visited different sections in the museum;2) after selecting 
these specific recordings, parts of the visit in which educators and students interacted were chosen.

Next, the communicative interactions were transcribed. The speakers' turns were organized in numbers separated by a dot (.) in the form X.Y, in which $\mathrm{X}$ is the recording and $\mathrm{Y}$ the sequence of interactions. Therefore, 2.4 means the fourth turn in the second recording. The following conventions were used in the transcriptions: ME1 and ME2 for museum educators who guided the group; the letters A-N to represent students individually; SS to represent more than one student talking at the same time; $\mathrm{T}$ to represent the teacher; NI for non-identified individuals; brackets for researcher's notes; and three dots between parentheses (...) to represent long pauses.

In the analysis, we traced a path related to contributions of Bakhtin and the Circle and the analytical model proposed by Lima and Giordan (2017) as follows: a) analysis of the social-historical context of the communication; b) identification and analysis of the object (discursive-object); c) identification and analysis of the communicative relations between subjects (discourse-answer); d) dialogue between the results and the literature to understand the museum educators' contexts of performance.

We understand that the unit of analysis must be the smallest element that congregates the characteristics of the phenomenon. Because the object of investigation is the communication between subjects, we understand that the unit of analysis must be grounded on stable elements that are capable of generating meanings and senses. Beforehand, the possibility of the word as a unit was discarded because words are essentially polysemic and their meanings depend on concrete situations of social communication. Therefore, the theme of the utterance was selected as a unit of analysis. According to Voloshinov (2017), "Theme is the upper, actual limit of linguistic significance" ${ }^{14}$ (p. 231), so the theme is given both by the linguistic elements and the extralinguistic elements of a situation. Voloshinov (2017) highlights that: "The theme of an utterance is concrete-as concrete as the historical instant to which the utterance belongs. Only an utterance taken in its full, concrete scope as an historic phenomenon possesses a theme" (p. 228) ${ }^{15}$.

\section{Interactions between educators and students}

Analyzing parts of a museum visit - Astronomy and Chemistry -, showed that the activities were centered on the museum educators' speech and on the objects of the exhibition. Even if the teacher was aware that the sections may not approach the themes discussed in class, such as atoms, subatomic particles - protons, neutrons, electrons, quarks, bosons, leptons - stars, galaxies, the universe (a fact that was confirmed), visiting both spaces was greatly expected.

In this context, two types of interaction were most frequent between museum educators and the visiting group: discourses with shifts of speakers but controlled by the educator, and the discourse that silenced students. Both are explained in the following.

14 Voloshinov, V. Marxism and the Philosophy of Language. New York: Seminar Press, 1973. p. 101.

15 See footnote 14. p. 100. 


\section{Case 1: Discourse with shift of speakers and controlled by the educator}

The first case is a part of an interaction in the Chemistry section of the museum, which lasted 34 minutes. Activities in the section consisted of the exhibition of experimental activities conducted by a museum educator. We understand that this activity has a script to organize the main actions, but the educator is free to construct the utterance and adjust procedures during the demonstration.

The space in which the activity was performed was a small amphitheater with a pulpit for the educator; a central station on top of which was the glassware, the reagents, a sink and a small cabinet. During the activity, students were sitting in rows on the steps, so they could all see the educator. The activity started 40 minutes into the visit and was mediated by an educator (ME1) that had not been with the group yet.

Part 1 (Figure 1) reveals an intense interaction between educator and students. The educator's utterances were answered, predominantly, by many students at the same time. We understand that this was due to the sort of questions she asked, addressed to the entire group: at first, there were questions to characterize the group that had ordinary answers (name of the school and their grade) - a type of standard interaction that takes place in science museums to understand the profile of the vising group. This standard interaction provided the educator with information to elaborate her utterances closer to the students' social horizon. This type of interaction, then, allowed information to circulate and contributed to the establishment of discourse-answer and discourse-object relations once the educator could rely on her knowledge of the school curriculum to assume the information and knowledge with which students would be able to interact as well as their level of scientific interpretation and their limitations. Next, the interaction was based on questions about sciences that demanded "yes or no" answers.

Figure 1. Transcription of the first part of the interaction between the museum educator and the students in the Chemistry section (continues)

\begin{tabular}{|c|l|}
\hline \multicolumn{2}{|c|}{ Part 1 [3 minutes 41 seconds] } \\
\hline Turn & Transcription \\
\hline 1.1 & ME1: Hi, guys, are you alright? \\
\hline 1.2 & SS: Yes. \\
\hline 1.3 & ME1: What school do you go to? \\
\hline 1.4 & SS: [name of the school] \\
\hline 1.5 & ME1: Ok, let's go. Where is your school? \\
\hline 1.6 & SS: Piracicaba \\
\hline 1.7 & $\begin{array}{l}\text { ME1: So, you're staying here in the lab with me, I'll just put on my gloves, my goggles, what } \\
\text { year are you? }\end{array}$ \\
\hline 1.8 & SS: Ninth grade. \\
\hline 1.9 & ME1: Let's go, you don't have chemistry yet, just sciences. Do you like the sciences? \\
\hline 1.10 & F: I was... it's uncle [teacher's name]. \\
\hline
\end{tabular}


Figure 1. Transcription of the first part of the interaction between the museum educator and the students in the Chemistry section (continuation)

\begin{tabular}{|c|c|}
\hline \multicolumn{2}{|r|}{ Part 1 [3 minutes 41 seconds] } \\
\hline Turn & Transcription \\
\hline 1.11 & $\begin{array}{l}\text { ME1: Let's go guys, let's start here [some students are chatting] The more you talk, the less you } \\
\text { see what I do here in the lab, this is our deal. Ok? Let's go. We are in the Chemistry Lab and } \\
\text { before we start the experiment, let me ask a classical question. What does Chemistry study? } \\
\text { For example, Biology studies animals and plants. What about Chemistry? }\end{array}$ \\
\hline 1.12 & SS: Reactions! \\
\hline 1.13 & $\begin{array}{l}\text { ME1: Reactions. That's it. Chemistry studies the transformations of the matter. That is why my } \\
\text { section matters; do you see here in my jacket? But what's matter, after all? }\end{array}$ \\
\hline 1.14 & SS: Everything that occupies a space. \\
\hline 1.15 & $\begin{array}{l}\text { ME1: Yes! Everything that has a volume that occupies a place in space. There's one more } \\
\text { property, right? }\end{array}$ \\
\hline 1.16 & B: Mass! \\
\hline 1.17 & ME1: Mass, exactly! So, give me one example of matter. Let's go, am I matter? \\
\hline 1.18 & SS: Yes! \\
\hline 1.19 & ME1: Are my clothes matter? \\
\hline 1.20 & SS: Yes! \\
\hline 1.21 & ME1: The liquid in here, is it matter? \\
\hline 1.22 & SS: Yes! \\
\hline 1.23 & ME1: Is the air matter? \\
\hline 1.24 & SS: Yes! \\
\hline 1.25 & ME1: Alright, is light matter? \\
\hline 1.26 & SS: No! \\
\hline 1.27 & ME1: The sound, the voice, the music, are they matter? \\
\hline 1.28 & SS: No! \\
\hline 1.29 & ME1: What about electricity? \\
\hline 1.30 & SS: Yes. No. \\
\hline 1.31 & $\begin{array}{l}\text { ME1: Yeah? Alright, then, let's go. Can we fill this balloon with electricity? Put some of it in } \\
\text { my hand and put it in here? }\end{array}$ \\
\hline 1.32 & SS: No. \\
\hline 1.33 & ME1: What about fire? \\
\hline 1.34 & SS: No! \\
\hline 1.35 & $\begin{array}{l}\text { ME1: No. So, all of this that I just said isn't matter, alright? Because it doesn't occupy a place } \\
\text { in space. Alright? So far, so good? }\end{array}$ \\
\hline
\end{tabular}

Source: The authors.

The shift of speakers, in this communication, is due to several factors, among which we highlight the beginning of the presentation when the educator tries to get closer to the students by asking them where they were from, where did they go to 
school, etc. This interaction involves turns 1.1 to 1.11 . Next, she indicates the type of activity to take a place in the museum - centered on dialogue and on the exhibition of practical activities - and requested students to stop chatting. The educator, then, makes general questions about Chemistry, such as "what does Chemistry study?" and "What is matter?", that led to simple, descriptive answers known to most students. The educator also verified whether students knew of any additional property of matter and if they were able to adequately understand this property (mass).

The questions posed by the educator were asked in sequence with an increasing level of difficulty. In order to assess what they knew about matter, the educator asked about different objects that ranged from daily objects, such as clothing, to invisible elements, and whether types of energy were matter (light, electricity and heat). Because the questions increased in difficulty, students could not come to a consensus, in turn 1.30, regarding the right answer. In the face of controversy, the educator presented an imaginary situation to help students think about the answer. The feedback given by the educator, even in the form of a simple question whose answer varied from yes to no, led to a situation in which students could engage in reflection and come to understand that energy was not matter, thus reformulating their answers.

This case indicated that the sequence of questions - even if conceived by researchers of the field as low demanding regarding the structure of the answers and their explanatory capacity (Lobato \& Quadros, 2018; Paula \& Lima; 2010; Silva et al., 2018) - can promote reflections that help restructuring thoughts, especially when it displays the contradiction and the complexity of choices.

This analysis of the interaction indicates a particular discourse-object relation, in which the educator had control of the associations that students could make because the dialogue was generated to prevent many variations in the students' interpretations. This discursive production was provided by the communicative strategy that relied predominantly on either/or questions. The educator limited and induced the evaluations students could make regarding the object.

During the interaction, there was no evidence that many social voices were present; however, the educator's attitude in situations of disagreement indicated the establishment of a monologic interaction in spite of the shift of speakers. The disagreement in turn 1.30 was followed by the educator's feedback aimed at correcting and allowing students to reformulate meanings regarding a scientific concept (mass). This type of action is expected and adequate to an educational setting at the same time it establishes that, in the activity, the scientific knowledge must be the grounding element to validate answers. Therefore, if other divergent voices from the scientific knowledge were present in the communication, they would be questioned.

The analysis of discourse-answer relations, in turn, indicates that the educator wanted to know with whom she was interacting, information that may be considered pertinent to her discursive elaboration. In turn 1.9, the educator recognized that students still do not take Chemistry at school, which could indicate that she was trying to adjust the 
words and the dialogue to a public likely unfamiliar with names and concepts frequently used in that museum section. This information can also have motivated the educator to verify what students understood of subjects from the Chemistry curriculum. Therefore, in the dialogue, it became explicit who were the social-historically situated subjects in the interaction, a fact that indicated concern with accessible communication for the students. One evidence of the educator's attempt to approximate discourses and their objects to the students' social horizon is seen in Part 2 when the educator showed that one of the reagents necessary for the reaction to be demonstrated was already known to many and that students had probably seen it (Figure 2).

Figure 2. Transcription of the second interaction between the museum educator and the students in the Chemistry section

\begin{tabular}{|l|l|}
\hline \multicolumn{2}{|l|}{ Part 2 [23 seconds] } \\
\hline Turn & Transcription \\
\hline 2.1 & $\begin{array}{l}\text { ME1: So, cool, and you'll need this salt here, this one is easy, you find it in drugstores, see } \\
\text { guys? The name is potassium permanganate. Have you heard of it? }\end{array}$ \\
\hline 2.2 & SS: Yeah. \\
\hline 2.3 & ME1: Potassium permanganate, alright, who here has had chickenpox? \\
\hline 2.4 & SS: Me. \\
\hline 2.5 & ME1: Who's had the chickenpox and took a bath of purple water? \\
\hline 2.6 & SS: Huh? Me \\
\hline 2.7 & $\begin{array}{l}\text { ME1: You took a bath with permanganate, alright, this salt here, it's good to cure those little } \\
\text { sores when you have chickenpox, to dry them out. Let's go. I'm going to put it here, to make } \\
\text { fire. }\end{array}$ \\
\hline
\end{tabular}

Source: The authors.

This Part 2 (Figure 2) demonstrated that ME1 was willing to establish a dialogue close to students, even if controlled by her. During the conduction of an experiment, the educator asked students to enunciate what they were observing and based on their utterances - that agreed with her expectations - she guided the analysis of the process.

Next, she continued the interaction in the same format with the assistance of two volunteer students - which, once again, showed that she was willing to make the activity interactive. In order to bring the theme closer to the students' reality, the mediator used an example from Forensic Chemistry using as reference a popular TV series, CSI (turns 3.20 to 3.23 in the following). Part 3 (Figure 3) took place after a brief explanation of exothermic reactions, followed by the conduction of an experiment manipulated by the museum educator assisted by two students. During the activity, the educator mixed two reagents (potassium permanganate and hydrogen peroxide) in order to boil hydrogen peroxide rapidly.

In Part 3 (Figure 3), we can see the educator repeats the strategy of conducting the discursive interaction. After the reaction and the production of smoke, she wanted to know students' interpretation, and they answered very generically. Although the 
answers were correct, in a section destined to Chemistry, it is expected that concepts and practices of the field be approached. Therefore, the educator reformulated her initial question to stress what she wanted for an answer: "what's the composition of the smoke?". Nonetheless, answers were still generic and/or divergent from the scientific discourse. There is a change, then, in the educator's strategy, who does not reformulate the question again but turns to sensorial analysis.

Figure 3. Transcription of the third interaction between the museum educator and the students in the Chemistry section (continues)

\begin{tabular}{|l|l|}
\hline \multicolumn{2}{|l|}{ Part 3 [3 minutes 4 seconds] } \\
\hline Turn & Transcription \\
\hline 3.1 & ME1: Let's go, guys, so what came out from the top? \\
\hline 3.2 & SS: Gases. Smoke. \\
\hline 3.3 & ME1: Smoke, but the smoke, what's in the composition of the smoke? \\
\hline 3.4 & SS: Gases. \\
\hline 3.5 & NI: Oxygen [several students answer] \\
\hline 3.6 & NI: Carbon dioxide. \\
\hline 3.7 & ME1: Come on! Let's analyze it, through observation, can we see oxygen? \\
\hline 3.8 & SS: No. \\
\hline 3.9 & ME1: No. Does anyone see the air we breathe? \\
\hline 3.10 & SS: No. \\
\hline 3.11 & $\begin{array}{l}\text { ME1: That's good, so, let's go, what comes out of here was water vapor, that we could see. } \\
\text { There's also oxygen, but we can't see it. The white smoke was water vapor. And if there's } \\
\text { vapor, it means that the tube is hot, right? So, how hot does the tube need to be, at least, } \\
\text { to evaporate water? }\end{array}$ \\
\hline 3.12 & D: 100. \\
\hline 3.13 & ME1: 100 degrees Celsius, but do you think it's just 100? \\
\hline 3.14 & D: No. \\
\hline 3.15 & $\begin{array}{l}\text { ME1: No, you saw how fast the water evaporated, so it was more than 100. I'll show you, } \\
\text { hold down here and move to the person next to you. Don't get attached to the tube, alright? } \\
\text { If you get attached to the tube, you know what happens. }\end{array}$ \\
\hline 3.17 & $\begin{array}{l}\text { SS: [Different reactions; the tube in which the experiment was conducted is actually a } \\
\text { Graduated cylinder, which is passed around the students. Meanwhile, the educator cleans } \\
\text { the station and the other glassware used thus far and prepare other reagents and glassware } \\
\text { for the next activity] }\end{array}$ \\
\hline 3.18 & $\begin{array}{l}\text { ME1: Guys, while you're looking at the tube, I'll move on here in the lab. } \\
\text { by the forensic team. Let's talk about Forensic Chemistry, alright!? Have you heard of it? }\end{array}$ \\
\hline 3.19 & SS: No. Yeah. \\
\hline $\begin{array}{l}\text { ME1: It's the part of Chemistry that deals with criminal analysis, right? Have you ever } \\
\text { watched it? }\end{array}$ \\
\hline E: He's addicted to it. \\
\hline 3.21
\end{tabular}


Figure 3. Transcription of the third interaction between the museum educator and the students in the Chemistry section (continuation)

\begin{tabular}{|l|l|}
\hline \multicolumn{2}{|c|}{ Part 3 [3 minutes 4 seconds] } \\
\hline Turn & Transcription \\
\hline 3.22 & SS: Yes. No. \\
\hline 3.23 & $\begin{array}{l}\text { ME1: CSI, and all that, they use a liquid called luminol, I have it here in my lab, right? } \\
\text { Luminol is used for what? To identify blood traces, the signs of blood in the scene of the } \\
\text { crime, alright?! So, come on, but I need a volunteer. Who wants to help me? }\end{array}$ \\
\hline 3.24 & F: ME! \\
\hline 3.25 & SS: Me, me, me, me. [several answers] \\
\hline 3.26 & ME1: Hold on; you can come. \\
\hline
\end{tabular}

Source: The authors.

In this analysis, the first question posed by the educator was aimed at making the students reflect on their answers and discard the interpretation that the smoke they saw was made of oxygen. It is interesting to observe how the educator used a particular form of discourse-object relation (the smoke is composed of oxygen) to establish a discourseanswer relation ("let's analyze it, through observation, can we see Oxygen?") that was more coherent with the scientific knowledge.

It is noteworthy, in the excerpt, the presence of other social voices, that is, voices from other spheres of human activity. It is possible to identify three voices that are from sciences, common sense and cultural and mediatic experiences. The educator's strategy relied on the use of this knowledge to deepen students' understanding and to consolidate scientific knowledge.

In turns 3.2, 3.4, 3.5 and 3.6, students presented answers that can be considered common sense. Albeit correct, in this case, the relationship between common sense and scientific knowledge was not a contradiction, but a simplification. The educator's strategy pointed out the divergence of these social voices - a fact that is expected since, after an educational activity in science, the grasp of scientific elements is desired from the public that can overcome in-depth and accuracy other forms of knowledge.

The voice that indicates experiences with culture and media was targeted by the educator in turns 3.20 and 3.23. As before, the relation between this voice and the scientific voice was collaborative and hierarchical, once it appeared to exemplify and contextualize the procedures, the techniques and the scientific concepts introduced by the educator.

Due to the absence of equipollence between social voices, both interactions display monologic characteristics because, even if there were any different social voices, in the dialogue, they were not independent nor had the same degree of validity. Scientific knowledge was the one that guided the valid interpretations of themes and phenomena being discussed, and it was also presented as "a ready-made truth", conditions that reinforce and justify our interpretation. 
In general, in this section, we could observe discursive interactions controlled by the educator. Nonetheless, her performance contributed to an interaction in which students could make their own statements at the same time she made elements available for them to expand their understanding of the subject. Even in situations that demanded the correction of an incorrect interpretation, the educator chose a strategy that led students to reinterpret the facts and correct the mistakes themselves, as in seen in the interactions in turns 1.29 and 1.31 and between turns 3.1 and 3.10. It is noteworthy that the educator used questions to understand, even if superficially, the characteristics of her public and searched for elements that could be associated to students' daily lives and interests, such as the chicken pox and the TV series, factors that contributed to the generation of a discourse that allowed the shift of speakers.

\section{Case 2: Discourses that silence students}

The Astronomy section was the last section in the museum to which students had access and the visit was mediated by a museum educator (ME2) different from that in case 1 (ME1). The visit lasted approximately 18 minutes and it started one hour and seventeen minutes into the museum visit.

The section dedicated to Astronomy was set in a place with dim lights and several museum objects (star models, explanatory models, practical activities, a piece of meteorite, screens with audiovisual explaining elements of scientific culture, etc.), which introduced and explained scientific concepts and phenomena as well as contextualized historically some facts related to science and the universe, such as the first space travels, the visit Einstein paid to Brazil etc.

Unlike the previous interaction, the visit to this section relied on moments of interaction with a museum educator (ME2) and freer moments, when the students could circulate around the room and interact with objects in the museum. It is important to stress how evident was the multiplicity of interactions among the students themselves when they could circulate freely around the room, in contrast with the low interactivity in the times the educator conducted the activity.

Part 4 (Figure 4) is composed of interactions between the students and the educator (ME2). Differently from ME1, we observe that the dialogue is more linear, with longer stretches of speaking time and explanation by ME2. The enunciation was first constructed based exclusively on the themes of the section, indicating that the educator never employed the strategy of knowing the audience to adjust her approach and to approximate her vocabulary to the students' social horizon. We highlight the absence of "standard interactions" to gather information on the audience. This indicates an educational and communicative perspective that is based on transmitting information for generic and ideal subjects. Also, there were no references to the spaces visited by the students before and that could dialogue with the section they were visiting, such as the Geology and Mineralogy sections. Therefore, the social-historic characteristics of the visit were not considered, not through the recognition of the visiting public or by 
resuming possible experiences the students had during the visit to the museum.

Discourse-object dialogic relations were found in this interaction, especially through questions posed by the educator that were followed by the students' answers. In Part 4, ME2 asked four questions, one about the Sun and one about its characteristics, one about gases and another about black holes. In addition, she asked three rhetorical questions, two involving doubts, and another six questions that tried to get more information from students and/or resumed one of the previous questions.

Figure 4. Transcription of the first part of the interaction between the museum educator and students in the Astronomy section (continues)

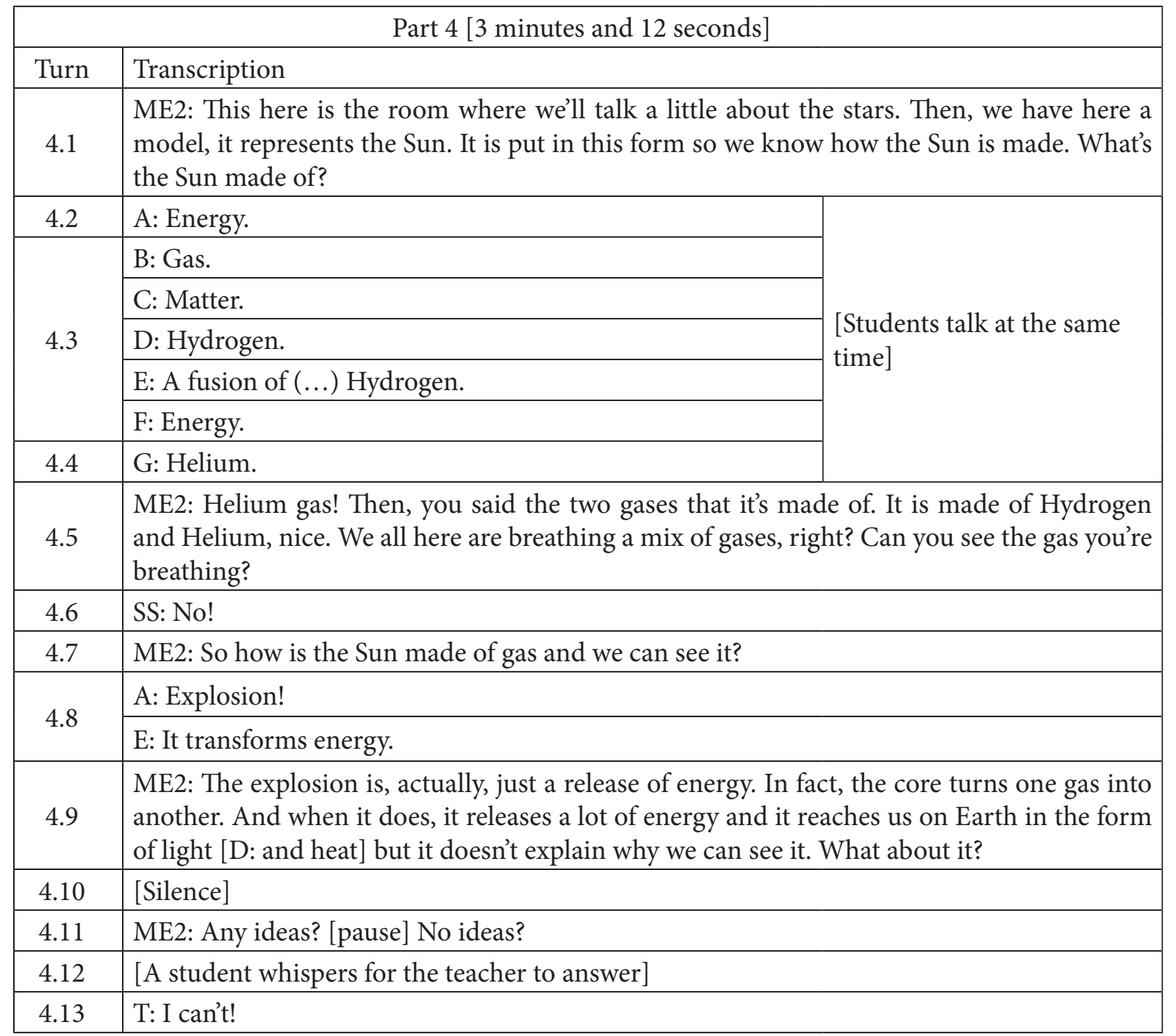


Figure 4. Transcription of the first part of the interaction between the museum educator and students in the Astronomy section (continuation)

\begin{tabular}{|c|c|}
\hline \multicolumn{2}{|r|}{ Part 4 [3 minutes and 12 seconds] } \\
\hline Turn & Transcription \\
\hline 4.14 & $\begin{array}{l}\text { ME2: Actually, the gas we're breathing is in a physical state we call it gas, right? And the Sun's } \\
\text { in a state we call plasma. Then, it is an ionized gas, that's why it has consistency. This fur here } \\
\text { represents that; this spot here is telling us that it's firmer than the rest of the Sun. Here, there's } \\
\text { a solar explosion, then the material comes out of the Sun and gets cold in space and when } \\
\text { it comes back, it has a different temperature. Then, when we take a picture from a satellite, } \\
\text { we can see the spots, depending on what you're trying to see in the Sun. Alright? There at } \\
\text { the core, it's more or less sixteen million degrees Celsius, to make that fusion, you need a lot } \\
\text { of pressure. If on the outside is only five thousand degrees Celsius, in the radius it gets to a } \\
\text { higher temperature than the Sun's external temperature. The Sun's the star that's closest to us, } \\
\text { but in the galaxy, there are stars bigger than the Sun. Five billion years from now, the Sun will } \\
\text { die. It'll run out of hydrogen to turn into helium, so there'll be only helium then it'll turn into } \\
\text { a giant red, then it'll shrink and explode into a Supernova. That is a theory; the other theory } \\
\text { is that it'll turn into a neutron star. Stars ten times the mass of the Sun turn into something } \\
\text { called a black hole. What's a black hole? }\end{array}$ \\
\hline 4.15 & [Silence] \\
\hline 4.16 & ME2: Any ideas? \\
\hline 4.17 & E: Is it some dark energy!? \\
\hline 4.18 & ME2: What? \\
\hline 4.19 & E: Is it some dark energy!? \\
\hline 4.20 & $\begin{array}{l}\text { ME2: So, dark energy and dark matter are different from a black hole! Any ideas? (...) Does } \\
\text { nobody have any ideas? I'm sure that in your minds, right now, you've already thought of } \\
\text { what a black hole is! Does nothing come to mind? (some students talk among themselves). } \\
\text { There are some people thinking it's a place that sucks it all in! }\end{array}$ \\
\hline 4.21 & A: It's a hole that drains things to get energy! \\
\hline 4.22 & T: Say it "A"! Say it out loud! \\
\hline 4.23 & A: It's a hole that drains things to get energy! \\
\hline 4.24 & ME2: What? \\
\hline 4.25 & A: It's a hole that drains things to get energy! \\
\hline 4.26 & $\begin{array}{l}\text { ME2: It's a hole that drains things to get energy! Then, the idea when you talk about a black } \\
\text { hole and you get the idea of a hole in our minds. But black hole is just a name for a region } \\
\text { in space that we can't see. And this region in space, what does it do? There's a star in this } \\
\text { region and then the light from the star disappears when it's near this region. Then, we call it } \\
\text { a black hole. But there are not just black holes, there are red holes, yellow holes. It depends } \\
\text { on the type of radiation that is emitted by this hole. In nature, the black hole is the only body } \\
\text { that emits a hundred percent radiation. Them, how do we know there's a black hole?! When } \\
\text { the satellite is studying that in space, in that region, it appears something we call a horizon } \\
\text { of events, then you see that radiation, but nothing can get close to a black hole, nothing we } \\
\text { know of, and nothing ever came out of one, so we know what is in there. So, this wormhole } \\
\text { stuff is just theory. And we're done with the stars, any questions? [Silence] No!? }\end{array}$ \\
\hline
\end{tabular}

Source: The authors. 
After the first question, it was evident the multiplicity of relations established around the object. The question asked by ME2, "What is the Sun made of?" (turn 4.1) generated seven different and coherent answers from students, some more generic such as "matter", "energy", and "gases" and other more complex such as "fusion (...) of hydrogen". The diversity of answers showed the interaction between the plurality of evaluations on the object of discourse, as well as the disposition of students to actively participate in the dialogue. However, in spite of the variety of interpretations, the educator chose to highlight two answers exclusively, those that expressed the desired information to the continuity of the discursive production: hydrogen and helium (turns 4.3 and 4.4). This interpretation is reinforced by the ME2's utterance in turn 4.5 ("Then, you said the two gases that it's made of".), which ends the possibility of more manifestations.

Therefore, the interventions were valued only when the answer coincided with the one expected by the educator, whereas the others were discarded independently of their occurrence, which is noted in the interactions from turns 4.1 to 4.5. In turn 4.5 , the educator highlighted the expected answer, enunciated in the previous turn, but she did not resume the other answers that were coherent as well. One of the discarded answers, the one by student "E" (turn 4.3), for example, went beyond the description of the chemical composition, indicating the physical process responsible for the formation of stars. It is possible to observe that the choice was made to develop the utterance, since none of the other answers was resumed, while the educator developed a linear speech without the possibility of exploring other themes and correlated objects. This fact can be interpreted as a strategy to prevent the dialogue from deviating from the discourse the educator elaborated beforehand. It also hints at an explicit relation of power that showed who detained power and who was deprived of it.

The educator, then, used the information given by the students to ask two questions that exclusively requested their agreement, that is, these questions were not oriented toward the development of the students' interpretation, much less to an open dialogue. The question in turn 4.5 served as a guide for another question "why can we see it?" (turn 4.7), that was answered by the words: "explosion" and "it transforms energy". Again, the answers did not meet what the educator considered to be correct, a fact that motivated her next turn, when she evaluated the students' answers as incorrect.

Similarly, in turn 4.9, a dialogic relation was established between the different evaluations of the discursive object. In this case, the educator interpreted relations as antagonistic by using her social position to determine that the students' evaluations were wrong. That fact showed a type of relation of power in which the educator held the power of truth and was not willing to negotiate meanings she interpreted with the students' utterances. Therefore, based on the educator's evaluation, it was possible to notice that only the meanings related to the ones she wanted to approach were valid.

After the evaluation, the educator asked the question again in three ways (turns 4.9 and 4.11), which was followed by the silence of students, thus showing that they could have felt intimidated and, consequently, less motivated to express their ideas 
freely. The only manifestation by a student, took the form of a whisper and requested the teacher to answer the question. It is not clear why the question was directed at the teacher. However, it is possible to notice that the student asked for help from someone that knew more of the subject to answer the question.

In turn 4.14, the educator summarizes another question (What's a black hole?), that initially did not prompt any answers from the students (turn 4.15). In the following turns, there was the attempt to dialogue after the educator repeated her question, however, it failed for two reasons: 1 ) the students did not have sufficient elements about the discursive object; 2) the educator's attitude, demanding accuracy in the students' answers rather than triggering diversity of opinions, even if divergent from the ones she expected. The educator's attitude may have inhibited students in expressing their opinions once there was a gradual decrease in the interactions between the students and the museum educator throughout the visit to the section.

During the dialogue, the presence of the voice marked by scientific knowledge was predominant. In some of the answers provided by the students, it is not possible to determine whether the interpretations were based on common sense, but, even so, they were isolated in the interaction. Evidently, the dialogue can be classified as monologic due to the exclusion of other voices that compose the discourse.

The plurality of coherent answers given in turns 4.2, 4.3 and 4.4 indicated a dialogic relation that corroborated with the production of meanings in accordance with scientific concepts, especially because it indicated the multiplicity of relations that can exist between explanatory elements of an object or phenomenon. This plurality can be seen as a mosaic of meanings shared by a group in the process of understanding a scientific concept. By choosing to highlight only two answers (hydrogen and helium), the educator formulated two other questions, a rhetoric one (4.5 "Can you see the gas you're breathing?") and one that demanded an explanation (4.7 "So how is the Sun made of gas and we can see it?"). This chain of questions could only be asked for the indicated answers. If the educator had highlighted answers such as "energy" and "fusion", she would need a different discursive orientation. Because the educator ignored coherent and valid interpretations, in accordance with the scientific knowledge, it is possible to claim that the basis of the monologic production was not related to the sphere of ideological creation (Science) but to the production of discourse.

The educator's attitude regarding the students' answers indicates an orientation in the discourse-answer dimension, which can be found both in the questions asked by her, as she tried to interact with the visitors, and in the visitors' interpretations, even the silent ones, who evaluated and positioned themselves before the utterances. Considering the subject and the limited knowledge students had on some of the topics, as well as the number of answers, it is possible to claim that the students' evaluation was to accept the ideas that were presented to them. This acceptance, then, inhibited the development of a dialogue with the presence of many voices, that is, a dialogue that showed the tensions in the discourse-object dimension. In the moments when there were disputes 
of interpretation, the conclusion resourced to the speech of authority claimed by the educator.

The absence of agreement with the interpretations that diverged from the educator's, whether in the scientific sphere or other spheres of human activity, showed a linear discourse based on the deficit model of science communication. It is important to stress the characteristics and limitations of the deficit model since, among many things, the communication relies on the transmission of scientific content, which, sometimes, can contain conceptions that disagree with the consensual scientific knowledge, such as in turns 4.14 and 4.26. Pointing out these mistakes is not aimed at disqualifying the content of the interactions in the museum, but for bringing forth the elements that should be approached in the professional education of museum educators, since the scientific knowledge has not cataloged any "colored holes" and the most accepted theory on the evolution of the Sun indicates that it may transform into a white dwarf after the red giant stage. These mistakes can happen, especially with complex themes or ones that are still in development by the scientific community. These issues - especially ones without consensus in the scientific community or that are in constant debate and scientific development (conceived as pertaining to the sphere of "science in action") - demand wide and updated knowledge on the area and its discussions, as well as the proper education for museum educators so they can be approached during guided visits. Therefore, they add complexity and other elements to the education of these professionals compared to the exclusive approach of the knowledge consolidated by science and appropriated by society (see Norberto Rocha, 2018; Marandino et al., 2020).

In that same section, the educator continued the guided visit and introduced another object to students, a model that represented an asteroid, as transcribed in Part 5 (Figure 5).

Part 5 (Figure 5) began with an explanation by ME2, followed by the students' utterances, and showed that students were interested in the object, so much so they could identify some of its physical properties, such as the smell. However, the level of information students had on the subject was superficial and it did not move beyond the assessment on the appearance of the object and its physical characteristics. It is also possible to see that, even after identifying the smell of the meteorite, students could not associate its composition to what was mentioned in turn 5.3 by the museum educator.

The excerpt reinforces our previous interpretation in relation to the silence caused by the educator, once the students did not comment on the object (meteorite) with her, nor did they try to answer her questions. Just a single student answered one of the seven questions asked by the educator. The educator herself acknowledged that the students' silence was strange when she said "You're very quiet. I don't know if what I'm talking about is boring or whether you're tired." (turn 5.4). We stress that the educator suggested that students should manipulate the meteorite; however, instead of trying to interact with her, the students chose to interact amongst themselves. On the one hand, the interaction between students presented greater plurality of manifestations because it 
was composed of the utterances of five subjects, on the other hand, the knowledge that constituted the dialogue was superficial and did not contribute to the production of new meanings that considered elements beyond the ones captured by perception.

Figure 5. Transcription of the second part of the interaction between the museum educator and the students in the Astronomy section

\begin{tabular}{|l|l|}
\hline \multicolumn{2}{|l|}{ Part 5 [3 minutes 20 seconds] } \\
\hline Turn & Transcription \\
\hline 5.1 & $\begin{array}{l}\text { ME2: Here on the side, there's a model: it represents an asteroid. A real one is more or less } \\
\text { twenty kilometers wide. Could it fit in this room? Could it fit in this museum? Could it fit the } \\
\text { neighborhood? }\end{array}$ \\
\hline 5.2 & G: No! \\
\hline 5.3 & $\begin{array}{l}\text { ME2: No, it's too big! That small one, over there, it's a meteorite, it was a meteor before. The } \\
\text { meteor, when it crosses the atmosphere, it creates attrition with the air, then it catches fire. } \\
\text { When you look at that light, you call it a falling star. When a meteorite hits Earth, it makes } \\
\text { meteor that hit Russian, did it turn into a meteorite? No, because it hit the ocean. That one is } \\
\text { more or less six thousand years old, and it is made of iron and nickel. Where are nickel and } \\
\text { iron formed in space? Any ideas? (Silence) }\end{array}$ \\
\hline 5.4 & $\begin{array}{l}\text { ME2: When the star is dying, it starts to gather heavier elements. Then, this iron and the } \\
\text { nickel are formed by the core of a start. The iron circulating there in your blood comes from } \\
\text { a star. All the chemical composition of our bodies comes from a star. Any doubts? You're very } \\
\text { quiet. I don't know if what I'm talking about is boring or whether you're tired. What? Guys, } \\
\text { here's what you're going to do, as you're so quiet, you can stand up, touch the meteorite and } \\
\text { smell your hand. After you see [incomprehensible]. }\end{array}$ \\
\hline 5.5 & H: It looks like a dog, look! The muzzle, the eyes. \\
\hline 5.6 & T: You're kidding, huh H! \\
\hline 5.7 & I: Not that one! \\
\hline 5.8 & L: Gross! The smell is bad. \\
\hline 5.9 & J: There, smell the Iron! \\
\hline 5.10 & T: Smell like what, J? \\
\hline 5.11 & J: Hello? \\
\hline 5.12 & T: Smells like what? What did you say? \\
\hline 5.13 & J: Iron! \\
\hline 5.14 & N: Guys, calm down! \\
\hline 5.15 & ME2: Then, here in the back, there are some (incomprehensible). \\
\hline 5.16 & $\begin{array}{l}\text { [Students walk around the room and interact with other museum objects and take } \\
\text { pictures.] }\end{array}$ \\
\hline
\end{tabular}

Source: The authors.

In this interaction, the discourse-object dialogic relation began with the educator's utterance, but this utterance became isolated and unresponsive to the students' interactions since, during the interaction, the ideas exposed by the museum 
educator were not resumed nor were any of the utterances directed at her. Therefore, the relationship students established with the educator's discourse appears to be isolated, so they could freely manifest their interpretations of the object.

Discourse-answer relations, in turn, were not evident in the interaction between the educator and the students. Even if the educator asked questions that allowed students to express their understanding, they remained silent. The silence was likely the product of a type of interaction established from the beginning of the visits in this section, in which the students' interpretations and ideas were left aside to preserve the educator's expected and possibly prepared/trained discourse.

Nonetheless, when we concentrate on the discourse-answer relation established among the students (from turn 5.5 to 5.13), it is possible to notice relations that indicate the use of ordinary language and the mobilization of acts that prompt students to certain actions, such as smelling the meteorite. Therefore, the interactions generated evident answers expressed by the interaction between them (agreement answers) as well as by the actions that were repeated to verify the experience reported by the first student.

Following Part 5, students were free to interact with the exhibition for approximately 10 minutes. The dialogue was resumed by the educator who gathered the group again to present an explanatory module on mankind's first trip to the Moon. Finally, we present the last excerpt of interaction between the museum educator and the students, which, once more, illustrates a form of silencing discourse. Part 6 (Figure 6 ) began after students moved inside the Astronomy section and took place during their accommodation into a different room, all the while they were chatting, some of them enthusiastically.

Similar to previous excerpts, we note the students' silence and the museum educator's explanatory approach (turn 6.10), which mentions museum objects in a factual form and outside the historical and scientific context: "And the first man to step on the Moon was Neil Armstrong, in the mission Apollo 11. On the panel next to it, there's a picture of Apollo 17". The description of the room and the objects made by ME2 did not favor students' manifestations in the interaction. In the next turn (6.13), a student manifested enthusiasm after the educator's report "This telescope is awesome!", but she did not take the opportunity to establish a dialogue on the topic. She continued to ignore what the student said and, again, she adopted an attitude of authority and ended the visit (turn 6.14). In this part, it is evident the students' disappointment with the utterances (turn 6.15) "Is it over? It is over!". As they realize the visit is coming to an end, student F asks the teacher to ask the ME2 a question "Talk about radiation." and the teacher, in turn, prompted him to interact with the museum educator. However, student $\mathrm{F}$, still embarrassed, preferred to ask a classmate to ask the question " $\mathrm{M}$, ask about the radiation, there! You can explain it better!" and added "That (...) that Men couldn't go to the Moon because there's so much (...) it needed a lot of lead to cross.... This dialogue between $\mathrm{F}$ and $\mathrm{M}$ and the teacher during the museum educator's utterances shows how much students were embarrassed about asking relevant questions for the interaction 
and for the space they were visiting.

Figure 6. Transcription of the third interaction between the museum educator and students in the Astronomy section

\begin{tabular}{|c|c|}
\hline \multicolumn{2}{|r|}{ Part 6 [1 minute 35 seconds] } \\
\hline Turn & Transcription \\
\hline 6.1 & NI1: We're on the Moon! \\
\hline 6.2 & NI2: I'll walk like that. [student simulates walking on the Moon slowly] \\
\hline 6.3 & NI3: Is that the Moon!? We're on the Moon! \\
\hline 6.4 & NI4: We're not on the Moon! \\
\hline 6.5 & NI5: We're on the Moon! \\
\hline 6.6 & NI6: We're on Earth! \\
\hline 6.7 & NI7: Technically. \\
\hline 6.8 & ME2: Guys! Move to the side, over to the wall. \\
\hline 6.9 & [chat about the position of students] \\
\hline 6.10 & $\begin{array}{l}\text { ME2: Over there is man's first footprint on the Moon! [fragment] And the first man to step } \\
\text { on the Moon was Neil Armstrong, in the mission Apollo 11. On the panel next to it, there's a } \\
\text { picture of Apollo 17. The astronauts that went to the Moon took a picture of our planet. Then, } \\
\text { the Picture there is real close to the natural size. On the ceiling, you can see every little dot is } \\
\text { a different galaxy. }\end{array}$ \\
\hline 6.11 & SS: Gee! \\
\hline 6.12 & ME2: It was taken with the Hubble telescope after a 127-hour exposition. \\
\hline 6.13 & C: This telescope is awesome! \\
\hline 6.14 & $\begin{array}{l}\text { ME2: Guys, do you have any questions? Any questions or curiosity? No!? This was the } \\
\text { Astronomy section that I just showed you and I hope you liked it. I leave open the invitation } \\
\text { to come back to Museum [Name], we have different sections and you've seen three of them. } \\
\text { Nowadays, they're eleven, plus the itinerant session. }\end{array}$ \\
\hline 6.15 .1 & C: Is it over? [dialogue 6.15 takes place during turn 6.14 ] \\
\hline 6.15 .2 & G: It is over! \\
\hline 6.15 .3 & D: Student fee is 3 reais. \\
\hline 6.15 .4 & F: Talk about radiation. [a student tells the teacher] \\
\hline 6.15 .5 & P: Talk about it! Ask her! [the teacher prompts the student to interact with the educator] \\
\hline 6.15 .6 & F: M, ask about the radiation, there! You can explain it better! \\
\hline 6.15 .7 & M: What? \\
\hline 6.15 .8 & $\begin{array}{l}\text { F: That (...)that Men couldn't go to the Moon because there's so much (...) it needed a lot of } \\
\text { lead to cross (...) Nevermind. }\end{array}$ \\
\hline 6.16 & $\begin{array}{l}\text { ME2: Now, I'll take you to the bus. I'm going to ask you to stick together until we're at the } \\
\text { parking lot. }\end{array}$ \\
\hline 6.18 & NI: We're leaving already? \\
\hline 6.19 & T: Yeah. \\
\hline 6.20 & NI: I liked it here so much! \\
\hline
\end{tabular}

Source: The authors. 
The interactions in this part indicated a dialogue based on a univocal discourseobject relation rather than a communication centered on the interlocutors' answers (discourse-answer). The preservation of exchange focused on an exclusive interpretation of the discursive object inhibited student's participation, who were not comfortable asking questions to the museum educator or to repeat their questions in case she did not hear them at first. The type of discourse established by the educator can be conceived as an isolated monologic dialogue. Voloshinov (2017, p. 192-193) ${ }^{16}$ highlights that "isolated monologic utterances all those ties that bind an utterance to the full concreteness of historical generation are torn away".

It is important to stress the educator's utterance in turn 6.14 ("Guys, do you have any questions? Any questions or curiosity? No!?") that contained two questions and one answer and lasted only three seconds. This fact is conceived as another indicator of a ready-made discourse, of an isolated monologic discourse, that does not prompt situations in which students can manifest according to their interests because no time was invested to allow students to manifest themselves and ask questions.

The interactions between ME2 and students also neglected the historical constitution of communication. It seems to us that the production of utterances was based on a previously elaborated and atemporal discourse. In the educator's utterance, the historical references were mostly based on scientific and technological knowledge and facts. On the other hand, the concrete historicity that determines the discursive chain and the forms of social interaction were rarely present in the educator's utterances, since most of the student's talk was discarded and did not interfere with the enunciations produced by her.

From a different perspective, the role of historicity became evident in the performance of students. In the 18 minutes they visited the Astronomy section, they realized the absence of space to present their own interpretations, knowledge and doubts in regards to the objects. Hence the restructuring of their actions. At the beginning of the section, they turned their questions toward the educator, but in the end, they interacted exclusively among themselves and with the teacher accompanying them.

Therefore, concerning the discourse-answer relation, the museum educator's utterance did not generate situations so that students could express their understanding of the museum objects. It is important to stress that producing an answer is one essential stage of the process of understanding (Lima, 2020), so that, at some point, even if outside the museum, students produced meanings about the visit, the objects and the knowledge with which they interacted. Notwithstanding, we understand that had they been given room to manifest and their answers had been used during the visit, the understanding of the information would have been deeper and more intense once they would be able to interact with the museum object, with the educator and with other students. This condition would enable them to elaborate, to re-elaborate, and deepen their answers and, consequently, their understanding of the themes and objects.

16 See footnote 14. p. 78. 


\section{Discussions and final considerations}

In the present case study, as we analyzed two sections of a visit by a group of $9^{\text {th }}$-grade elementary school students to a science museum, our data showed that in both sections the dialogue was centered on and conducted by the museum educators and their knowledge, rather than focused on students. The utterances established by these educators were classified as monologic, once both considered the "social voice" of science to be hierarchically superior or more valid. Albeit monologic, the utterances displayed distinct characteristics, especially when their dialogic were analyzed.

We observed, in the first case, that the educator's enunciative structure was guided by discourse-answer and discourse-object relations, once she tried to approach knowledge from the scientific culture to rescue elements from the social horizon of students, an utterance that can also be understood as "guided discussion". Marandino (2008) highlights that guided discussion is based on questions about the content of the exposition and makes room for some of the students' positionings, although controlled by the educator. That means that the performance of the museum educator considered (albeit modestly) that students had some knowledge and were able to reformulate them with scientific knowledge.

In the second case, the discursive production was predominantly guided by a discourse-object relation in which the disagreeing interpretations were not considered in favor of the production of an explanatory model. The relation discourse-answer was not prompted by the educator's approach, so the students had to make efforts to understand and, in the end, left the section with questions. Therefore, the dialogue approached the content of the exposition in a linear and unilateral way - characteristics that reinforce the interpretation of a communicative model closer to the deficit model - in an enunciative structure that silenced students. Therefore, the educator's attitude indicated communicative and educational processes that were predominantly based on the information, not on interpersonal relations and in the relations that the subjects could establish with objects and knowledge approached by the museum environment. From the perspective of museum education, we can consider the interaction between the museum educator and visitors fits the "lecture mode" (Marandino, 2008), in which there is very little interaction and works as a monologue. These claims become even more explicit when we notice that, in the analyzed excerpts, the questions asked by the educator were predominantly for agreement or descriptions.

It is noteworthy that explanations through the transmission of information can also be observed in the first case: if the students' answers were removed from the verbal interaction, it is possible to see that there is no significant loss of the content in the discourse. This indicates that the questions made by the educator did not aim at composing and elaborating an utterance that involved and explored student's perspectives, thus promoting heteroglossia.

Despite the differences in cases 1 and 2, we verified that, in both verbal interactions between the museum educators and the students, there were difficulties in 
establishing a communication that considered several interpretations of the enunciative objects. Focusing on the discourse-object relation, generally, allowed the observation of the scarcity of multiple voices regarding the phenomena represented by the museum objects or the educator's enunciations. Analysis of the discourse-answer relations indicated superficial interactions that discarded undesired enunciations. On the other hand, when we tried to understand the difference between the volume of interaction to students, in both cases, in addition to the educators' attitudes, the questions asked by them had different characteristics. Whereas the questions asked in the Chemistry section demanded answers, mostly, from the students' experience, the question asked in the Astronomy section demanded knowledge of scientific concepts. These characteristics can be further investigated in future works that aim to identify discursive productions that contemplate both domains (previous experiences and scientific knowledge) and how they can contribute to the establishment of a dialogue between museum educators and visitors.

Results indicate the importance of discursive analysis that contemplates the historicity of communication, given that simple questions characterized by low cognitive demand were capable of producing reflections that helped rethinking the object of investigation in the first case. This result showed that the analytical activity should also focus on the historicity of interactions rather than only on the classification of sentences or questions isolated from context.

Therefore, results found in our study are related to Rodari and Merzagora (2007) claim in which museums can eventually behave "as any other media, like emitters that offer information to an indifferent and passive audience, rather than taking advantage of the possibility of establishing a conversation with the visitors" (p. 9) ${ }^{17}$. Therefore, we agree with Marandino (2008), who defends that museum visitations are more than speech:

One must pay attention to the other, to trigger curiosity, to establish contact and facilitate the democratization of knowledge produced by museums, either through conversations or through activities used to reach the hearts and minds of whoever comes into a museum for one day (p. 23) ${ }^{18}$

The format of interactions can be related to the institution's conception of school visits and how they must be conducted as well as the professional education and working conditions of museum educators. We do not dispose of this information in our data, however, our analysis allowed us to establish dialogues with literature that treat the relation between the interactions and the formation of educators.

17 Original: "como qualquer outra mídia, como emissores que oferecem informações a uma audiência indiferenciada e passiva, em vez de tirar vantagem da possibilidade de estabelecer uma conversação com seus visitantes"

18 Original: "Há que se prestar atenção no outro, se instigar a curiosidade, se estabelecer o contato e facilitar a democratização do conhecimento produzido nos museus, seja por meio de conversas, seja através de atividades utilizadas para atingir o coração e a mente de quem entra em um museu por um dia”. 
On the one hand, school visits guided by museum educators are common in Brazilian museums and serve educational purposes; on the other hand, there are challenges to be explored in the future and in educational practices for those professionals. Oftentimes, the fact that educators are used to pre-established discourses on the museum sections and objects means they can have difficulties in conducting dialogues based on the students' interests and participation. The challenge can be even greater because deepening the discussions with visitors depends on complex, updated and vast knowledge that approaches scientific issues that are in development or are still controversial in scientific communication. Therefore, our results indicate the need to reinforce initial and continued professional qualification for museum educators, especially in regards to overcoming the deficit model, so their work is not restricted to the presentation of what is exhibited, but that the professional feels confident and prepared to open possibilities for complex dialogues that consider different voices and knowledge.

Hence our agreement with Roldi et al. (2019) who claim that professional education for museum educators needs to set aside a model of science communication centered on ready-made and little flexible discourses, based on assumptions of what the public does not know and focus on a communication that expands the knowledge of all the actors involved and that is open to change. Therefore, the authors claim that "it is also necessary to prepare for improvisation and to dialogue about science", considering that the discursive interactions are two-way paths that allow negotiation of knowledge and interests in which educators and visitors "can build several types of knowledge" (Roldi et al., 2019, p. 986). According to Marandino (2008), "what is most desired at the end of the visit is not, particularly, the quantity of learning about the exhibition, but the quality of human interactions that were established" (p. 22) ${ }^{19}$.

Finally, given the data and the discussions presented in this case study involving discursive interactions between museum educators' interactions and school students, we expect to contribute to reflections and to future studies concerning the practices and the professional education of science museum educators in Brazil.

\section{Acknowledgment}

The second author thanks Faperj for the project Jovem Cientista do Nosso Estado [E-26/202.763/2019]. Both authors thank the science museum, the museum educators and the teachers and students for their participation.

19 Original: “o que se almeja ao final da visita não é especialmente a quantidade do que foi aprendido sobre a exposição, mas sim a qualidade das interações humanas estabelecidas” 


\section{References}

Bakhtin, M. (2006). Os gêneros do discurso. In Bakhtin, M. Estética da Criação verbal. $4^{\mathrm{a}}$ ed. trad. Paulo Bezerra. Martins Fontes, pp. 261-306.

Bakhtin, M. (2010a). Questões de Literatura e de Estética. 6a ed. Hucitec.

Bakhtin, M. (2010b). Problemas da poética de Dostoiévski. Trad. Paulo Bezerra. 5a ed. Forense Universitária.

Bamberger, Y. \& Tal, T. (2006) Learning in a personal context: levels of choice in a free choice learning environment in science and natural history museum. Science Education, 91(1), 75-95 https://doi.org/10.1002/sce.20174.

Barba, M. D. L. P., Castillo, J. P. G. D., \& Massarani, L. (2019). Public engagement in science: Mapping out and understanding the practice of science communication in Latin America. Anais da Academia Brasileira de Ciências, 91(1), 1-16. https://doi. org/10.1590/0001-3765201920171000

Brait, B. (2005). Bakhtin e a natureza constitutivamente dialógica da linguagem. In Brait, B. Bakhtin, dialogia e construção do sentido. (2a ed.). Editora UNICAMP.

Carlétti, C., \& Massarani, L. (2015). Explainers of science centres and museums: a study on these stakeholders in the mediation between science and the public in Brazil. Journal of Science Communication, 14(2), 1-17. https://doi.org/10.22323/2.14020201

Cazelli, S. (2005). Ciência, Cultura, Museus, Jovens e Escolas: Quais as relações? [Science, Culture, Museums, Young People and Schools: What are the relations?] Tese (Doutorado). Faculdade de Educação - Pontifícia Universidade Católica do Rio de Janeiro, PUC/RJ, Brasil. Rio de Janeiro.

Cazelli, S., \& Coimbra, C. A. Q. (2008). Avaliação formal na educação não formal. Rio de Janeiro: Associação Brasileira de Avaliação Educacional - ABAVE.

Cazelli, S., \& Valente, M.E. (2019). Incursões sobre os termos e conceitos da educação museal . [Incursions on the terms and concepts of museum education]. Revista Docência e Cibercultura 3(2), 18-40. https://doi.org/10.12957/redoc.2019.40729

Costa, A. (2019). A Formação Inicial e Continuada De Educadores Museais: Projeto Em Construção [Initial and continuing training of museum educators: Project under construction]. Revista Docência e Cibercultura 3(2), 67-89. https://doi.org/10.12957/ redoc.2019.44693

Costa, A., Castro, F., Chiovatto, M., \& Soares, O. (2018). Educação Museal. In Caderno da PNEM. Brasília: Ibram.

Faraco, C. A. (2009). Linguagem \& diálogo: As ideias linguísticas do círculo de Bakhtin. Parábola editorial. 
Gomes, I., \& Cazelli, S. (2016). Formação de mediadores em museus de ciências: saberes e práticas [Science museum mediators' education: knowledge and practices]. Ensaio: Pesquisa em Educação em Ciências, 18(1), 23-46. https://doi.org/10.1590/198321172016180102.

Griffin, J. (2004). Research on students and museums: Looking more closely at the students in school groups. Science Education, 88(S1), S59-70. https://doi.org/10.1002/ sce. 20018

Lima, G. S. (2016). O professor e a divulgação científica: apropriação e uso em situações formais de ensino [The teacher and the science communication: appropriation and use in formal educational situation]. (Tese de doutorado), Faculdade de Educação da Universidade de São Paulo. https://doi.org/10.11606/T.48.2016.tde-16082016-093959

Lima, G. S (2020). O conceito de compreensão em Bakhtin e o Círculo: reflexões para pensar o processo educativo. Bakhtiniana - revista de estudos do discurso, 15(3), 297317. https://dx.doi.org/10.1590/2176-457348458

Lima, G. S., \& Giordan, M. (2017). Características do discurso de divulgação científica: implicações da dialogia em uma interação assíncrona [Features of science communication: implication of dialogism in an asynchonousinteraction]. Investigações em Ensino de Ciências, 22(2), p. 83-95. http://dx.doi.org/10.22600/1518-8795.ienci2017v22n2p83

Lobato, A. C., \& Quadros, A. L. (2018). Como se constitui o discurso de professores iniciantes em sala de aula. Educação \& Pesquisa, 44, 1-21. http://dx.doi.org/10.1590/ s1678-4634201709162258

Marandino, M. (2001). O conhecimento biológico nas exposições de museus de ciências: análise do processo de construção do discurso expositivo. 451f. [Tese de Doutorado em Educação - Faculdade de Educação, Universidade de São Paulo, São Paulo].

Marandino, M. (Org.). (2008). Educação em museus: A mediação em foco. São Paulo: GEENF, Faculdade de Educação, Universidade de São Paulo.

Marandino, M., \& Ianelli, I. T. (2012). Modelos de Educação em Ciências em Museus: análise da visita orientada [Science education models in museums: analysis of guided tours]. Ensaio: Pesquisa em Educação em Ciências, 14, 17-33. https://doi. org/10.1590/1983-21172012140102

Marandino, M., Norberto Rocha, J., Cerati, T. M., Scalfi, G., De Oliveira, D., \& Lourenço, M. F. (2018). Ferramenta teórico-metodológica para o estudo dos processos de alfabetização científica em ações de educação não formal e comunicação pública da ciência: resultados e discussões. JCOM AL, 01. https://doi.org/10.22323/3.01010203

Marandino, M., Pugliese, A., Monaco, L., Milan, B., \& Scalfi, G. (Orgs.) (2020). Práticas educativas e formação de públicos de museus: Relações entre ciência, sociedade e temas controversos. (1ed.). FEUSP. 
Martins, L. C. (2006). A relação museu/escola: teoria e prática educacionais nas visitas escolares ao Museu de Zoologia da USP [The museum/school relation: educational practice and theory on school visits to the Museum of Zoology of USP]. Dissertação (Mestrado) Faculdade de Educação, Universidade de São Paulo, São Paulo.

Massarani, L., Poenaru, L. M., Norberto Rocha, J., Rowe, S., \& Falla, S. (2019). Adolescents learning with exhibits and explainers: The case of Maloka. International Journal of Science Education, Part B. https://doi.org/10.1080/21548455.2019.1646439

Mora, M. D. C. S. (2007). Diversos enfoques sobre as visitas guiadas nos museus de ciência. In Massarani, L., Matteo, M., \& Rodari, P. Diálogos \& ciência: mediação em museus e centros de ciência. Rio de Janeiro: Museu da Vida/Casa de Oswaldo Cruz/ Fiocruz, p. 21-26.

Norberto Rocha, J. (2018). Museus e centros de ciências itinerantes: análise das exposições na perspectiva da Alfabetização Científica [Mobile science museums and centres: analysis of their exhibitions from the science literacy perspective]. 2018. 449p. [Tese de Doutorado em Educação - Faculdade de Educação, Universidade de São Paulo, São Paulo]. https:// doi.org/10.11606/T.48.2018.tde-03122018-122740

Oliveira, G. C. G., Turci, C. C., Teixeira, Brunno M., Silva, E. M. A., Garrido, I. S., \& Moraes, R. S. (2014). Visitas guiadas ao Museu Nacional: Interações e impressões de estudantes da Educação Básica [Guided visits to National Museum: interactions and impressions of Basic Education students]. Ciência \& Educação (Bauru), 20(1), 227-242. https://doi.org/10.1590/1516-731320140010014

Paula, H. F., \& Lima, M. E. (2010). Formulação de questões e mediação da leitura [Guiding reading activities in a science teaching program: the role of questioning on reading]. Investigações em Ensino de Ciências, 15(3), 429-461. https://www.if.ufrgs.br/ cref/ojs/index.php/ienci/article/view/257

Piqueras, J., \& Achiam, M. (2019). Science museum educators' professional growth: Dynamics of changes in research-practitioner collaboration. Science Education, 103(2), 1-29. https://doi.org/10.1002/sce.21495

Queiroz, G. R. P. C., Krapas, S., Valente, E., Damas, E., Freire, F., \& David, E. (2002). Construindo Saberes da Mediação na Educação em Museus de Ciências: O Caso dos Mediadores do Museu de Astronomia e Ciências Afins / Brasil .[Constructing knowledge about the mediation knowledge in education at science museums: the case of the mediators of the Astronomy and Related Sciences Museum/Brazil]. Revista Brasileira de Pesquisa em Educação em Ciências, 2(2), p.77-88. https://periodicos.ufmg.br/index. $\mathrm{php} / \mathrm{rbpec} / \mathrm{article} / \mathrm{view} / 4144$

Rodari, P., \& Merzagora, M. (2007). Mediadores em museus e centros de ciência: Status, papéis e treinamento. Uma visão geral europeia. In Massarani, L. (org.). Diálogos \& ciência: mediação em museus e centros de Ciência. Rio de Janeiro: Museu da Vida/Casa de Oswaldo Cruz/Fiocruz. 
Rodrigues, F. M. E. A. \& Afonso, A. S. C. (2015). A natureza das interações verbais durante visitas de estudo à seção de ótica de um museu de ciência [The nature of verbal interactions during schoolfield tripsto the optical section of a science museum]. Revista Brasileira de Pesquisa em Educação em Ciências, 15(1), 173-194. https://periodicos. ufmg.br/index.php/rbpec/article/view/4307

Roldi, M. M. C., Silva, M. A. J., \& Campos, C. R. P. (2019). Diálogo com mediadores de Museus de Ciência [Dialogues with mediators in Science Museums]. Ciência \& Educação (Bauru), 25(4). https://doi.org/10.1590/1516-731320190040009

Scalfi, G., Marques, A. C. T. L., Iszlaji, C., Milan, B., Norberto Rocha, J., \& Marandino, M. (2019). Análise do processo de alfabetização científica em crianças em espaços de educação não formal e divulgação da ciência. ACTIO: Docência em Ciências, 4(3), 386410. http://dx.doi.org/10.3895/actio.v4n3.10533

Shaby, N., Ben-Zvi Assaraf, O., \& Tal, T. (2018). An examination of the interactions between museum educators and students on a school visit to science museum. Journal of Research in Science Teaching. https://doi.org/10.1002/tea.21476

Silva, R. L., Souza, G. M., \& Santos, B. F. (2018). Questionamentos em aulas de química: um estudo comparativo da prática pedagógica em diferentes contextos sociais. Revista Brasileira de Pesquisa em Educação em Ciências, 18(1), 69-96. http://dx.doi. org/10.28976/1984-2686rbpec201818169

Valente, M. E., Cazelli, S., \& Alves, F. (2005). Museus, ciência e educação: Novos desafios [Museums, science, andeducation: New challenges]. História, Ciências, Saúde - Manguinhos, (Vol. 12) (suplemento), p. 183-203. https://doi.org/10.1590/S010459702005000400010

Volóchinov, V. N. (2017). Marxismo e filosofia da linguagem: Problemas fundamentais do método sociológico na ciência da linguagem. Editora 34. 


\section{Guilherme da Silva Lima \\ Federal University of Ouro Preto Institute of Exact and Biological Sciences \\ Department of Physics \\ Ouro Preto, Minas Gerais, Brazil glima@ufop.edu.br \\ Jessica Norberto Rocha \\ Cecierj Foundation, and Rio de Janeiro, Rio de Janeiro, Brazil jessicanorberto@yahoo.com.br} National Institute of Public Communication of Science and Technology

Editor in charge

Lúcia Helena Sasseron 